\title{
Why Do Stock Prices React to the Fed?
}

\section{Hui Guo}

$\mathrm{O}$ bservers of financial markets have noted that monetary policy actions sometimes have a large effect on the equity market; stock prices respond rapidly and positively (negatively) to unexpected monetary easing (tightening), e.g., an unexpected decrease (increase) in the federal funds rate target. This behavior is consistent with rational capital asset pricing models, in which a stock's price is equal to the discounted future cash flow of income to the owner of the stock. That is, many financial economists argue that, if the equity premium - the rate of return that investors demand on stocks relative to the risk-free rate of interest-is approximately constant, a monetary tightening raises the risk-free rate and thus the discount rate, which in turn lowers stock prices.

Alternatively, a monetary tightening might lower stock prices by adversely affecting future cash flows. Bernanke and Gertler (1989) show that this effect can be important if (i) firms have insufficient internally generated funds to finance new projects and (ii) external funds are more expensive than internal funds. ${ }^{1}$ In particular, they argue that the premium on external funds is negatively related to a firm's collateral or net worth. Therefore, a monetary tightening, by reducing net worth, increases the cost of external financing and forces liquidity-constrained firms to operate at lower scale.

A distinct implication of this credit channel of monetary transmission is that monetary policy has a greater impact on small firms than on large firms because small firms usually have less retained earnings and thus are more vulnerable to adverse liquidity shocks. Also, the effect should be more pronounced during economic recessions, when liquidity is scarce, than during economic expansions, when liquidity is generally more abundant. Therefore, we would expect stock prices of small firms to respond more strongly to monetary innovations than those of large firms during economic downturns, although not necessarily during economic upturns.

Guo (forthcoming) analyzes the stock market reaction to unanticipated changes in the federal funds rate target in the periods 1974-79 and 1988$2000 .^{2}$ In the 1990s, the United States enjoyed the longest economic expansion since World War II. Business conditions were not so favorable in the late 1970s: The U.S. economy suffered from a severe recession and high inflation after the 1973 oil crisis and stock prices fell steeply as well. Thus, these two periods provide an opportunity to investigate the asymmetric effect of monetary policy on equity prices.

The accompanying chart plots the average response of stock prices to an unanticipated 1-percentage-point increase in the federal funds rate for stock portfolios formed on market capitalization, ranging from the smallest stocks (decile 1) to the largest stocks (decile 10). As expected, all stock portfolios reacted negatively to a monetary tightening in both periods. Interestingly, the absolute value of the response decreases monotonically with firm size in the 1970s: It is 2.7 percent for the smallest stocks, compared with 1.1 percent for the largest stocks, which is a statistically significant difference. In contrast, there is no obvious relation between the response to a monetary tightening and firm size in the 1990s. Therefore, these results are consistent with a credit channel of monetary transmission.

\footnotetext{
${ }^{1}$ Bernanke, Ben and Gertler, Mark. "Agency Costs, Net Worth, and Business Fluctuations." American Economic Review, March 1989, 79(1), pp. 14-31.

${ }^{2}$ Guo, Hui. "Stock Prices, Firm Size, and Changes in the Federal Funds Rate Target.” Quarterly Review of Economics and Finance (forthcoming).
}

\section{Reaction of Stock Prices to a 1-Percentage-Point Increase in the Federal Funds Rate Target 1974-79 and 1988-2000}

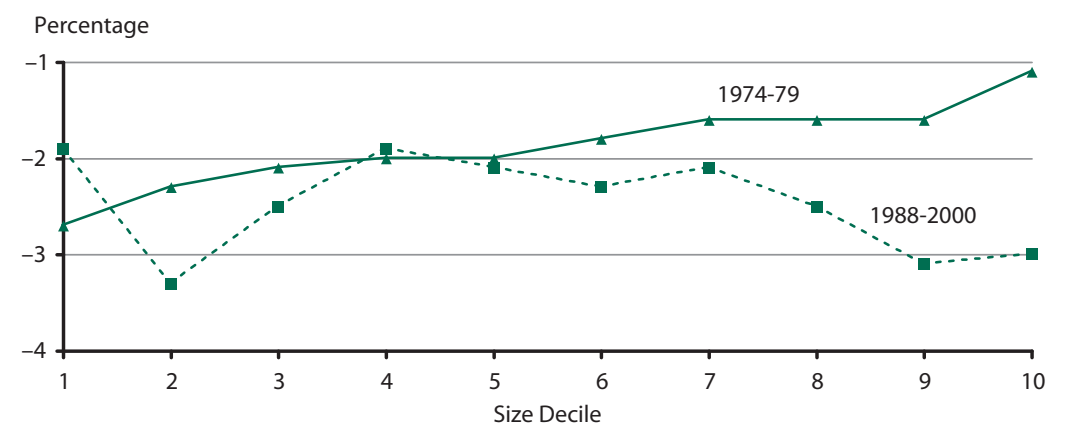

SOURCE: Guo (forthcoming). 